\title{
E-government Attempts in ESCWA Member Countries
}

\author{
Hasan Charif and Maya Ramadan \\ United Nations Economic and Social Commission for Western Asia (UNESCWA), \\ Sustainable Development and Productivity Division, P.O.Box 8576, Beirut, Lebanon \\ hcharif@escwa.org.1b, ramadan@un.org
}

\begin{abstract}
Many ESCWA member countries have felt the need to initiate egovernment applications thus making use of the latest information and communication technologies. However, none of these countries has yet achieved a well developed and fully functional e-government system, in spite of the plans put and sporadic actions taken for this endeavor. On the other hand, countries that resisted for some time the incorporation of ICT in governmental organizations and in citizen's everyday life, have felt the urgency of having national plans taking such innovations into consideration, otherwise they will be left behind in the stream of development.
\end{abstract}

\section{Introduction}

E-government allows for more transparency, greater convenience, smoother flow of information, better coordination between different agencies, rapidly delivered services for citizens and businesses, less corruption, revenue growth, cost reduction, and service provision for 24 hours over 7 days per week. If all of this is gained, what hampers e-government from moving-off? Barriers to e-government can be summarized in the following factors: resistance to change, lack of public awareness, public skepticism, poor telecommunications infrastructures and services, lack in human capital readiness, poor information security, hardware and software availability, and public access to Internet for common people, etc...

McConnell International report on e-readiness stated six ESCWA countries as having the potential to impact the new global economy. These countries are Egypt, Jordan, Kuwait, Lebanon, Saudi Arabia and United Arab Emirates. However none of these countries seem to satisfy the conditions needed for full transactions for egovernment and e-business [1]. Though e-government provides a wide range of information for decision makers to benefit from, it does in many ways threaten the control and power entitled to political leaders [2].

This is a comparative study describing the situation of ESCWA member countries with regard to e-government applications with consideration of the cultural and political contexts of these countries. Comparative studies concerning e-government applications hold special importance for many reasons: they allow countries sharing similar culture and geographical location to find common grounds and identify common obstacles, thus opening the door for joint planning and coordination for future action. Furthermore, knowing that e-government system is a new concept, internationally as well as locally, and that there is no standard blueprint to launch it,

The original version of this chapter was revised: The copyright line was incorrect. This has been corrected. The Erratum to this chapter is available at DOI: 10.1007/978-3-540-44836-5_33

M.A. Wimmer (Ed.): KMGov 2003, LNAI 2645, pp. 310-318, 2003.

(C) Springer-Verlag Berlin Heidelberg 2003 
gathering the different experiences in this field allows one country to benefit from another's experience (let it be success or failure) particularly established best practices. Finally, such comparative studies tend to be carried out by non-profit and non-politically oriented organizations, thus giving them an objective and transparent dimension [3], [4], [5].

\section{Countries Experience}

\subsection{Bahrain}

The Bahraini society seems ready to make use of IT in daily life, this is reflected through the growing number of Internet and mobile users; the number of mobile phones is almost ten times more than the fixed phone lines. The National Bank of Bahrain has introduced a new service allowing customers to make online transactions [6]. On the other hand the Bahraini government has set for itself a goal to become the telecommunications hub of the gulf [7]. Thirty ministries and departments have been connected to each other, which facilitates administrative procedures, like purchasing, auditing, budgeting and human resources management. This project was directed by the Ministry of Finance and National Economy, and is expected to positively affect the productivity in the concerned ministries [8]. Furthermore, the government had put under trial an e-voting system, called the (2D) Bar Coding Technology. This system holds personal information on every voter and allows citizens to voice out their opinions effectively and efficiently [9]. As for the commerce, the Bahraini government is still drafting a telecommunication act to promote open market and an e-commerce environment [6]. This year Paramount has been given the major role in dealing with information security in Bahrain [10]. Caution ought to be considered when sending politically suspicious emails or launching a Web site that might hold a threat to the ruling family, jail will be the measure taken to punish the suspect [11], [12]. Bahrain is working on developing laws for e-commerce that will keep its reputation as the financial capital of the Middle East [13].

\subsection{Egypt}

Internet access is affordable for the average Egyptian citizen. The government has an e-government plan that will start by building a media city and smart villages. These villages will provide software development and ICT training. Furthermore, once the plan is implemented it will provide a network linking ministries [14]. An Egyptian company is building an Internet infrastructure promising to procure a very fast connection [15], [16]. The Egyptian government committed itself to reduce software piracy and enforce copyright laws [17]. An official Web site provides wide range of information in a one-stop-shop manner [18]. The government is keen on guaranteeing the climate for IT to flourish; legislations fostering e-signature are underway, international agreements promoting trust in the progress towards an IT society are signed [19]. Nilesoft is committed to develop e-commerce sector in Egypt. This company considers that both the financial sector and the number of Internet users are encouraging to seriously tackle such a project [20]. 


\subsection{Iraq}

Until few months ago Internet connection was not available to the Iraqi community. Previously Internet was allowed merely in the ministries, and sending emails was not possible even in the ministries. Nowadays Internet cafes are widespread and it is even possible to have Internet at home. However, there is one Internet provider in Iraq (Urulink) and it is handled by the government. Hotmail, Yahoo or other similar email services are not possible, Urulink will deny access to such services. Home Internet is considered expensive for the average Iraqi costing about 25 USD each three months so usually citizens opt for Internet cafes [21]. It is worth mentioning that until the present moment mobile phones are not allowed in Iraq. Back in 1999, computer spare parts were not allowed to enter Iraq due to UN sanctions after the Gulf War [22], [23].

\subsection{Jordan}

In 1999, King Abdullah II announced his commitment to strengthen IT sector in Jordan. The REACH initiative (Regulatory framework, Estate, Advancement, Capital, Human resources) was launched. REACH is based on public-private partnership aiming to deliver e-services to citizens, businesses and government [24]. Jordan IT Community Centre was launched on December 2000 in order to spread computer and Internet literacy among inhabitants of remote areas. Computers have even been installed in Bedouin and rural areas to facilitate information access and improve the economic condition of women, students and others from different sectors. Computer skills are already taught in public schools as early as elementary levels [25], [26], [27]. Home Internet connection is also accessible to any citizen [28]. However the digital gap between the poor and the rich is still big in Jordan due to the high cost of connectivity. The government is planning to connect universities and schools (by 2003) and to liberalize the telecommunications sector (by 2005) [29]. Few months ago, the Ministry of Information and Communications Technology held a meeting for civil servants from over a hundred government institutions to discuss their roles and responsibilities in the development of e-government in Jordan [30].

\subsection{Kuwait}

Internet is widely used in Kuwait and the connection is fast. Every citizen in Kuwait beyond the age of nine has an ID card with a pin number; this card is used for a multitude of purposes like searching for a job and many others. Soon enough this ID will be used for financial transactions. This has already solved the problem of long queues in government departments, hospitals and others. Furthermore, unlike other gulf countries, telecommunications sector in Kuwait is liberalized which encourages both businesses and consumers [31], [32]. The National Bank of Kuwait is providing secure online services allowing the use of credit card for purchase and other transactions [33]. 


\subsection{Lebanon}

Lebanon is one of the first countries in the region to have Internet access open to the public. Internet connection penetrated the community as early as 1994, reaching universities and schools as well as average citizens' homes [34]. On the other hand rural areas are not privileged as urban areas with telephone system. The communication and Internet access costs in Lebanon are one of the highest in the region. This situation may change with the privatization of the telecommunications sector. Currently, the Lebanese government is interested in developing e-government. Lebanon has a modern infrastructure throughout the country. Thousand of computers have been deployed, civil servants have been trained on ICT products, and ICT awareness campaigns are run by the government. A one-stop-shop Web page is now available facilitating access to information for citizens [35]. The old law for intellectual property rights has been lately updated to suit the new technologies and the parliament approved it in 1999, which opened the door for many international ICT companies to launch new branches in Lebanon. However, actual market shows that this law is not being respected, for example $80 \%$ of software in Lebanon are pirated. The most well developed e-commerce is found in the banking sector [36], [37]. The complete e-strategy for Lebanon is under preparation by the Office of the Minister of State for Administrative Reform (OMSAR) in collaboration with many academics, policy makers, private businesses, citizens and others. This strategy will be ready by the end of year 2002 [38].

\subsection{Oman}

Internet is currently available for the Omani community [39]. The Omani government is trying to promote IT in the society. For example, the government is trying to increase Omani graduates in software and IT related disciplines, and the latest technologies have been installed in Sultan Qaboos University to make this plan possible [16], [40]. The Ministry of Civil Services is working to build a network connecting 45 ministries with the Ministry of Finance and the Ministry of Civil Services; this project will allow human resources management to update information regarding 86,000 government employees [41]. On last October the government signed a contract to launch the smart card containing personal information for both citizens and residents of the Sultanate; this card is supposed to allow the accomplishment of many public services like getting a driving license, voting, money withdrawal and many others [42]. The Central Bank of Oman is planning to develop the infrastructure necessary for electronic banking products and services [43]. Intellectual property rights is a serious matter in Oman; three large companies in Oman have been invaded because of their possession of illegal software and they have been given a week to legalize these software [44]. TradaNet is a new company launched in year 2000 and is now leading e-commerce in Oman [45].

\subsection{Palestine}

A report issued by Human Rights Watch in 1999 mentioned that the Palestinian Authority didn't try to control Internet content accessible to the public. Palestinians 
can have access to information covering a wide range of political and human rights information. This online freedom is making up for the shortage in publications and media due to the war situation [46].

\subsection{Qatar}

Internet services in Qatar is provided by one agent, Qatar Public Telecommunications Corporation (Q-Tel); no other Internet supplier is allowed to enter the market without an official governmental approval [47]. In September 2000 the government announced its will to have e-government; the e-government plan will be implemented by 2004 hoping to provide electronically $74 \%$ of the government activities offered by 22 ministries for both residents and citizens [48], [49]. It is worth mentioning that Qatar was the first Arab Country to announce its will to have e-government [16]. Qatar e-Commerce Committee was introduced to deliver within two years and a half the strategy for e-commerce with individuals and businesses [50].

\subsection{Saudi Arabia}

Saudi Arabia gained access to the Internet in 1994, however it wasn't before 1999 that the general public was able to make use of this service; furthermore, the connection is still not fast and the Internet service providers are asking the Saudi government to improve the infrastructure [16], [51], [52]. It is known that the government censors some Web sites [53]. The Saudi government is developing a national e-government plan and the related legislations [54]. Acknowledging the scarce human power in the IT field, e-government plan will give special attention to human capital and IT education [52], [55]. A government committee has been assigned to formulate a law to protect information security. The first steps that have been undertaken were training government employees [56]. Though the number of Internet users is showing an average growth of $8 \%$, and the IT sales in the Kingdom make more than $40 \%$ of the region's, it was proven that the general public doesn't yet trust the concept of egovernment [52], [57], [58]. This trust problem could be due to two main factors: infrastructure and security [59]. The Ministry of Interior is taking actual steps to launch Smart Card containing information including fingerprints and enabling its holder to have access to a range of public services [60]. Furthermore, there is a plan to establish an IT hub and science park in Jeddah [16].

\subsection{Syrian Arab Republic}

Syria has the most expensive Internet connection rate in the Middle East, allowed only through a local service provider. In 1997 Internet started in Syria, however the public didn't have access to it [16], [61], [62]. Until now the government constantly checks incoming and outgoing emails [63]. The Syrian Telecommunications Establishment blocks certain Web site. However the Syrian government has noticed the drawbacks of having poor Internet services. This not only affects residents of Syria, but it makes foreigners reluctant to visit the country especially if they rely on daily emails to run their work. Thus the government is seriously considering the improvement of its IT infrastructure while encouraging e-business and e-literate society [64]. 


\subsection{United Arab Emirates}

The eminent achievement in e-government is Dubai Internet City. Dubai has started a plan to provide 100 percent of its GDP from non-oil sources by 2010. Dubai Internet city, built on 163 hectares surface area, will shift the economy towards IT, multimedia and telecommunications businesses. It is already acknowledged internationally and hosting important IT meetings. International standards of the City have attracted big IT companies like Microsoft, Oracle, IBM, Hewlett-Packard, MasterCard International, Arabia Online, Compaq, and many others. Sheikh Mohammed bin Rashid al Maktoum, Crown Prince of Dubai, inaugurated Dubai Internet City on October 2001 (as scheduled 18 months earlier) and asked civil servants to provide all public services online otherwise lose their jobs. By 2003 every schoolchild will be provided a computer and Internet access [65], [66], [67]. Zayed University is offering a new MBA programme in e-commerce for professionals working in both the private and the public sector [68]. Dubai police is providing eleven services on the Internet and eight services on the WAP (wireless application protocol) [69]. Payment of traffic fines, renewal of driving license and many other services are now possible through WAP [70]. As for e-security, it is more or less protected by the government; for example, fines must be paid by Internet criminals but jail was never a possible verdict [56]. UAE scored the second on 'e-government index' in the Middle East region, after Israel [71].

\subsection{Yemen}

Yemen started a 10 years project in e-government aiming to guarantee more efficient services to citizens. There is one Internet provider for Yemen (Teleyemen) and connection is possible to the public; however some Web sites are blocked. Some services are already provided online, like payment of postal services. It is worth mentioning that Yemen scored the least in 'e-government index' in the region [71], [72], [73], [74].

\section{References}

1. Ready? Net. Go! Partnership Leading the Global Economy. McConnell International (2001)

2. Dahan, M.: Internet Usage in the Middle East: Some Political and Social Implications. Department of Political Science. The Hebrew University of Jerusalem www.mevic.org/papers/inet-mena.html

3. Van Bastelaer, B.: e Europe and User Aspects of ICT. Cost Working Paper No.1 (2001) http://www.info.fundp.ac.be/ cita/publications/e_Europe.pdf)

4. Rubino-Hallman, S.: E-Government in Latin America and the Caribbean. Reinventing Governance in the Information Age. CLAD (2002)

http://www.clad.org.ve/fulltext/0043107.pdf

5. Risk e-Business: Seizing the Opportunity of Global e-Readiness. McConnell International (2000) http://www.mcconnellinternational.com/ereadiness/ereadiness.pdf 
6. Communication in Bahrain. Trade Partners UK http://www.tradepartners.gov.uk/telecom/bahrain/profile/overview.shtml

7. Assignment $\mathrm{B}$, Information Infrastructure, Telecommunications and International Perspectives. Nova Southern University (2000)

8. Bahrain Claims Regional e-Government Lead. M3 New Media Consulting http://www.m3newmedia.com/bahclaimrege.html

9. Bahrain Become Middle East's First e-Voters. Symbol News (2001) http://www.symbol.com/news/pressreleases/pr_releases_inter_bahrain.html

10. Affan, M.: Paramount Brings Full Security Solutions Portfolio to Gitex 2002. ITP (2002) http://www.itp.net/news/103390742974222.htm

11. Bahrain Blocks Opposition Websites. New Monday (2002) http://www.newmonday.co.uk/News/1130509,

12. The Internet in the Mideast and North Africa: Free Expression and Censorship. Human Rights Watch (1999) http://www.hrw.org/advocacy/internet/mena/summary.htm

13. Corder, R.: Bahrain Drives Toward e-Commerce Laws. ITP (2002) http://www.itp.net/news/101963076345767.htm

14. Regulatory Development, Mediterranean Area, Synthesis of Master Reports (2001) http://www.eu-esis.org/esis2reg/synthMED7.htm

15. Seizing e-Government Opportunities: Assessment, Prioritization and Action. McConnell International, The World Bank Group (2001) http://unpan1.un.org/intradoc/groups/public/documents/apcity/unpan003917.pdf

16. E-Initiatives in the GCC Region, Vol. 2, No.11. Middle East Intelligence Bulletin http://www.meib.org/articles/0012_me2.htm

17. Egypt Launches e-Government Initiative with Microsoft. The Egyptian State Information Service (2001) http://www.sis.gov.eg/online/html4/o040421.htm

18. http://www.alhokoma.gov.eg/

19. The Government Now Delivers. Ministry of Communications and Information Technology http://www.mcit.gov.eg/

20. Intershop and Nilesoft Address Egyptian e-Commerce. ITP http://www.itp.net/news/100600796822224.htm

21 Internet Arrives in Iraq. Aberdeen News (2002) http://www.aberdeennews.com/mld/aberdeennews/news/world/4165387.htm

22. The Internet in the Mideast and North Africa: Free Expression and Censorships- Iraq. Human Rights Watch (1999) http://www.hrw.org/advocacy/internet/mena/iraq.htm

23. Reply to Human Rights Watch Letter Received From Officials of Iraq. Human Rights Watch (1998) http://www.hrw.org/advocacy/internet/mena)

24. The REACH Initiative (http://www.reach.jo/about.shtml

25. Volunteer Brings Computers to the Bedouin. Computer World (2000) http://www.computerworld.com/careertopics/careers/training/story/0,10801,524 80,00.html

26. Jordan IT Community Centers. JITCC Web site http://www.jitcc.gov.jo/mission.htm

27. IS Promotional Activities. Summary Report. ESIS Extension (2001)

28. Reply to Human Rights Watch Letter Received From Officials of Jordan. Human Rights Watch (1998) http://www.hrw.org/advocacy/internet/mena

29. A Road Map for Developing IT Services in Jordan. Jordan Ministry of Information and Communications Technology (2002) http://www.mopc.gov.jo/news2.asp?id=330

30. Civil Servants to Discuss e-Government Portal. The Jordan Times (2002) http://www.jordantimes.com 
31. Should We Carry a Personal Identity Card? http://government.blogspot.com/2002_07_07_government_archive.html

32. GCC Insights: Kuwait Ahead of the Rest in Telecom Liberalization. Gulf News (2002) http://www.gulf-news.com/Articles/news.asp?ArticleID=58890,

33. Corder, R.: Our Gulf and NBK Agree on e-Ccommerce. ITP (2001) http://www.itp.net/news/98077342820809.htm

34. Regulatory Developments. Lebanon Master Report. EU-ESIS (2001)

35. http://www.informs.gov.lb/

36. IS Promotional Activities. Summary Report. EU-ESIS (1999-2000)

37. The Lebanese e-Government Experience. OMSAR (2002)

38. E-Strategy for Lebanon. UNDP http://www.undp.org.lb/programme/governance/ict4dev/eStrategy.html,

39. OmanTel - Oman Telecommunications Company (http://www.omantel.net.om

40. HP Switch Technology Brings Multimedia Applications to Omani Students. HP http://www.hp.be/egov/en/references/om_quaboos.asp),

41. Times of Oman http://www.tariq.net/english/news13.htm

42. Multi-Purpose Card to Usher in e-Government. Times of Oman (2002) http://www.timesofoman.com/newsdetails.asp?newsid=17383.

43. CBO Proposes Electronic Fund Transfer System Omani Information Center (2002) http://www.omaninfo.com/cgibin/webnews/ShowArticle.asp?article_id=682232083

44. Omani Anti-Piracy Raids. Arab Trust (2002) http://www.arabtrust.com/midnews/more.html\#Oman\%20anti-piracy\%20raids

45. Portal on Oman's Non-Oil Exports Launched http://www.khaleejtimes.co.ae/ktarchive/270902/middleeast.htm

46. The Internet in the Mideast and North Africa: Free Expression and Censorship. Human Rights Watch (1999) http://www.hrw.org/advocacy/internet/mena/summary.htm

47. Reply to Human Rights Watch Letter Received from Officials of Qatar. Human Rights Watch (1998) http://www.hrw.org/advocacy/internet/mena

48. Qatar Launches e-Government Plan. World Information Technology and Services Alliance Newsletter (2000) http://www.witsa.org/news/00aug.htm

49. Qatar's e-Government Project Making Progress. E-Government Project to be Implemented in 2004. Development Gateway (2002) http://www.developmentgateway.org/node/130619/news/item?item_id=295644

50. Wilson, G.: Qatar Builds e-Government Portal. ITP http://www.itp.net/features/97556902273780.htm

51. Is the World e-Ready? Maybe Not. US-Egypt Presidents' Council (2000) http://www.us-egypt.org/istheworld.html

52. Al-Sudairy, M. A. T.: Electronic Government (eGov): Implementation Strategies. King Abdul Aziz University (2002) http://www.egov.org.sa/new/ecom/ecom_02speakers.asp)

53. The Internet in the Mideast and North Africa: Free Expression and Censorship. Human Rights Watch (1999) http://www.hrw.org/advocacy/internet/mena/summary.htm

54. Kingdom's Interest in e-Government is Growing Rapidly. Saudi e-Commerce (2002) http://www.egov.org.sa/new/ecom/ecom_index.asp.

55. 1000 Schools to be Equipped by Kingdom's Internet Initiative. Requirements Valued at Over 480 Million USD. Saudi e-Commerce (2002) http://www.egov.org.sa/new/ecom/ecom index.asp.

56. Corder, R.: GCC Governments Race to Create Cyber-laws. ITP (2001) http://www.itp.net/news/98973640889530.htm 
57. Participate at the Heart of the Largest and Fastest Growing Market in the Middle East. eCommerce Saudi Arabia (2002) http://www.recexpo.com/html/ecomm.html

58. Internet Users ... Official Interest ... Drive Sector's Growth in Full Speed. e-Commerce Saudi Arabia http://www.recexpo.com/html/ecomm.html

59. Browne, C.: Saudi e-Commerce Conference Lauded by Major Saudi Industry Experts. ITP (2001) http://www.itp.net/news/98578363361827.htm

60. Contracts Signed for Smart Card Technology. Arab News (2002) http://www.arabnews.com/Articles.asp?ID=18543

61. The Internet in the Middle East and North Africa: Free Expression and Censorship. Syria. Human Rights Watch (1999) http://www.meib.org/articles/0012_me2.htm

62. The Internet in the Mideast and North Africa: Free Expression and Censorship. Human Rights Watch (1999) http://www.hrw.org/advocacy/internet/mena/summary.htm

63. Blakeley, C. J., Matsura, J. H.: E-Government. Is e-Democracy Inevitable?

64. Syria, A New IT Strategy. Special Exclusive Report. http://government.blogspot.com/2002_11_10_government_archive.html

65. E-Government Launch on Schedule (2001) http://www.sheikhmohammed.co.ae/news

66. Dubai Grows as Region's e-Hub (2001) (http://www.sheikhmohammed.co.ae/news,

67. Dubai: New Chip on the Block (2000) http://www.atimes.com/reports/B128Ai01.html

68. Zayed University to Offer MBA in e-Business (2000) http://www.sheikhmohammed.co.ae/news

69. Dubai Police Launch e-Government System (2001) http://www.sheikhmohammed.co.ae/news

70. Renewal of Driving License on the Net (2000) http://www.sheikhmohammed.co.ae/news

71. Reply to Human Rights Watch Letter Received from Officials of Yemen. Human Rights Watch (1998) (http://www.hrw.org/advocacy/internet/mena

72. Yemen Kicks off US\$ 60 Million e-Government Initiative. ITP (2002) http://www.itp.net/news/103405825848780.htm

73. Electronic Payment Online. Yemen Times (2002) http://www.yementimes.com/02/iss39/lastpage.htm

74. Benchmarking e-Government: a Global Perspective. Assessing the Progress of the UN Member States. United Nations Division for Public Economics and Public Administration, American Society for Public Administration (2002) 